\section{THE CORRESPONDENCE OF WALTER \\ BENJAMIN, 1910-1940}

My most esteemed Mr. Buber:

The problem of the Jewish spirit is one of the most important and persistent objects of my thinking. Your flattering offer, ${ }^{1}$ for which I must thank you, affords me the possibility of giving expression to my thoughts. Yet only in a conversation could I expect the most essential prerequisite to be met, i.e. freeing these thought from their larger contexts and defining specific points of departure. Only this could settle the question of our collaboration and the form it would take. For this reason, I would like to ask for an opportunity to talk about this, should you be coming to Munich in the next month, or should I manage a visit to Berlin at Christmasunfortunately, however, this is very uncertain.

Most respectfully yours,

Walter Benjamin

1. To collaborate on Buber's journal, Der Jude.

Munich July 1916

My most esteemed Doctor Buber:

I had to wait until 1 had a conversation with Mr. Gerhard Scholem ${ }^{1}$ before making up my mind about my basic attitude toward your journal, Der Jude. After this conversation, I was in a position to decide whether I could possibly contribute to it. Because, in view of how intensely I disagreed with so many of the contributions to the first volume-especially their position on the

\section{AS CORRESPONDÊNCIAS DE WALTER BENJAMIN, 1910-1940}

Jamie Barteldes

Munique

4 Konigin St

Maio de 1916

Estimado Senhor Buber,

O problema com o espírito judeu é um dos mais importantes e persistentes objetos de meu pensamento. Sua oferta lisonjeira ${ }^{1}$, pela qual eu te agradeço, me garante a possibilidade de dar expressão aos meus pensamentos. Todavia, apenas em uma conversa poderia eu esperar o pré-requisito mais essencial ainda por ser atingido, i.e libertar estes pensamentos destes contextos maiores e definir pontos específicos de partida. Apenas isso poderia decidir a questão de nossa colaboração e a forma como ela se daria. Por esta razão, eu gostaria de solicitar uma oportunidade de conversar sobre isso. Você virá à Munique no próximo mês ou deveria eu visitar Berlin no Natal? Infelizmente, no entanto, isso é bastante incerto.

Atenciosamente,

Walter Benjamin

1. Colaborar no periódicode Buber, DerJude

Munique Julho de 1916

Estimado DrBuber,

Eu precisei esperar até que conversássemos com o Sr. Gerhard Scholem ${ }^{1}$ antes de me decidir sobre minha atitude básica diante de seu periódico, Der Jude. Depois dessa conversa, eu pude me decidir se haveria a possibilidade de eu contribuir para ele, pois diante do quão intensamente eu discordo com muitas contribuições do primeiro volume 
European war-my awareness that, in reality, my attitude toward this journal was and could be no other than my attitude toward all politically engaged writing was obscured. The beginning of the war finally and decisively revealed this to me. Moreover, I understand the concept of "politics" in its broadest sense, in which it is now consistently used. Before going on, let me say that I am fully aware that the following thoughts are still inchoate and that, where their formulation might sound apodictic, the reason is that what is foremost in my mind is their fundamental relevance to and necessity for my own practical behavior.

The opinion is widespread, and prevails almost everywhere as axiomatic, that writing can influence the moral world and human behavior, in that it places the motives behind actions at our disposal. In this sense, therefore, language is only one means of more or less suggestively laying the groundwork for the motives that determine the persons's actions in his heart of hearts. What is characteristic about this view is that it completely fails to consider a relationship between language and action in which the former would not be the instrument of the latter. This relationship would hold equally for an impotent language, degraded to pure instrument, and for writing that is a pitiful, weak action and whose origin does not reside within itself, but in some kind of Payable and expressible motives. On the other hand, these motive can be discussed; others can be juxtaposed to them, and thus the action is '(fundamentally) placed at the end as the result of an arithmetic process, tested from all sides. Every action that derives from the expansive tendency to string words together seems terrible to me, and even more catastrophic where the entire relationship between word and deed is, to an ever-increasing degree, gaining ground as a mechanism for the realization of the true absolute, as is the case among us now.

I can understand writing as such as poetic, prophetic, objective in terms of its effect, but in especialmente com a posição deles na guerra Européia - minha percepção de que, na realidade, minha atitude diante de toda escrita politicamente engajada se tornou obscurecida. $\mathrm{O}$ começo da guerra finalmente e decididamente revelou isto a mim. Além disso, eu entendo o conceito de "política" em um sentido mais amplo, no qual ele é agora consistentemente utilizado. Antes de prosseguir, deixe-me dizer que estou plenamente consciente que os pensamentos a seguir ainda são muito rudimentares e que sua formulação possa soar apodítica, a razão é que o que está em minha mente é sua relevância fundamental e a necessidade de meu próprio comportamento prático.

É opinião generalizada e prevalece em quase todos os lugares como axiomática de que a escrita pode influenciar o mundo moral e o comportamento humano, posicionando as motivações atrás das ações a nosso dispor. Desta maneira, portanto, a linguagem é apenas um meio para sugerir mais ou menos o lançar de bases para as motivações que determinam as ações das pessoas em seus íntimos. O que é característico sobre essa visão é que ela falha por completo em considerar o relacionamento entre linguagem e ação quando a linguagem não é instrumento da ação. Essa relação seria equilibrada diante de uma língua impotente, resumida a um puro instrumento, diante de uma escrita miserável, diante de uma ação fraca e cujas origens não residem em si mesmas, mas em algum tipo de motivação dizível e que possa ser expressa. Por outro lado, essas motivações podem ser discutidas; outras podem ser justapostas a elas e, desta forma, a ação é (fundamentalmente) colocada ao fim como o resultado de um processo aritmético, testado em todas as suas variáveis. Toda ação que se deriva de uma tendência expansiva de amarrar palavras umas às outras me parece terrível e ainda mais catastrófica quando a completa relação entre a palavra e o ato é, em um nível crescente, ganhar espaço como um mecanismo de realização da verdade absoluta, como é o caso entre nós agora.

Posso entender a escrita desta forma como poética, profética e objetiva em termos de efeito, 
any case only as magical, that is as unmediated. Every salutary effect, indeed every effect not inherently devastating, that any writing may have resides in its (the word's, language's) mystery. In however many forms language may prove to be effective, it will not be so through the transmission of content, but rather through the purest disclosure of its dignity and its nature. And if I disregard other effective forms hereaside from poetry and prophecy-it repeatedly seems to me that the crystal-pure elimination of the ineffable in language is the most obvious form given to us to be effective within language and, to that extent, through it. This elimination of the ineffable seems to me to coincide precisely with what is actually the objective and dispassionate manner of writing, and to intimate the relationship between knowledge rind action precisely within linguistic magic. My concept of objective and, at the same time, highly political style and writing is this: to awaken interest in what was denied to the word; only where this sphere of speechlessness reveals itself in unutterably pure power can the magic spark leap between the word and the motivating deed, where the unity of these two equally real entities resides. Only the intensive aiming of words into the core of intrinsic silence is truly elective. I do not believe that there is any place where the word would be more distant from the divine than in "real" action. Thus, too, it is incapable of leading into the divine in any way other than through itself and its own purity. Understood as an instrument, it proliferates.

For a journal, the language of the poets, of the prophets, or even of those in power does not come into question. Neither do song, psalm, and imperative, which, on the other hand, may have totally different relationships to the ineffable and may be the source of an entirely different magic. The only thing at issue is objective writing. Whether a journal will achieve it cannot be humanly foreseen, and probably not many journals have done so. But I am thinking of the Anthenauem. I am just as incapable of composing writing designed to have an effect as I am of understanding it. (Intrinsically, my essay mas de qualquer maneira alguma, apenas tão mágica quanto como não-mediada. Todo efeito salutar, de fato, todo efeito que não seja inerentemente devastador, que qualquer escrita possa ter, reside em seu próprio (da própria palavra, da própria linguagem) mistério. De todas as muitas formas que a linguagem possa se mostrar eficiente, não será pela transmissão de conteúdo, mas sim pela pura revelação de sua dignidade e de sua natureza. $E$, se eu desprezo outras formas eficientes aqui - á parte da poesia e profecia - continuo a achar que a eliminação cristalina da linguagem inefável é a mais óbvia forma que é nos dada para ser eficiente dentro da língua e, dessa forma, através dela. Esta eliminação do indizível parece para mim coincidir precisamente com o que é, de fato, a maneira objetiva e desapaixonada de escrever e criar intimidade com 0 relacionamento entre 0 conhecimento e a ação precisamente dentro da mágica lingüística. Meu conceito de objetivo e, ao mesmo tempo, meu estilo altamente político e minha escrita é este: gerar interesse no que foi negado para a palavra; apenas onde esta esfera da ausência de discurso se revela em seu poder puramente indizível pode a fagulha mágica surgir entre a palavra e sua motivação, onde a unidade dessas duas reais intensidades moram. Apenas o mirar intensivo das palavras até o âmago do silêncio intrínseco é realmente eficiente. Eu não acredito que haja qualquer lugar onde a palavra possa estar mais distante do divino do que em sua ação "real". Desta forma, é incapaz de levar ao divino de qualquer outra maneira do que por si mesma e através de sua própria pureza. Compreendida como instrumento, ela prolifera.

Para o periódico, a linguagem dos poetas, dos profetas ou até mesmo daqueles no poder não entra em questão. Nem muito menos a canção, o salmo ou o imperativo, os quais, por outro lado, podem ter uma relação completamente diferente com o indizível e pode ser a fonte de uma mágica completamente diferente. A única coisa em questão é a linguagem objetiva. Saber se um periódico conseguirá alcançar isso é humanamente impossível de prever e provavelmente não muitos periódicos conseguiram. Mas estou pensando no Anthenaeum. Sou tão incapaz de elaborar uma 
in Das Ziel' ${ }^{2}$ was entirely in keeping with the sense of what I have said above, but that was very hard to tell since it appeared in what was most inappropriate outlet). In my case, I will learn from what is said in Der Jude. And just as my inability to say something clear on the question of Judaism at this point coincides with the journal's inchoate stage, there is nothing to prevent us from hoping that there may yet be a more favorable coincidence in the stages of our development.

I may be able to come to Heidelberg at the end of the summer. I would then be very happy to attempt to enliven through conversation what, at this point, I have been able to express so imperfectly. And, from that vantage point, it might even be possible to say something about Judaism. I do not believe that my way of thinking is un-Jewish in this respect.

Most respectfully,

Yours, Walter Benjamin

1. Scholem was with WB from June 16 to 18.

2. "Das Leven der Studenten." escrita feita para ter um efeito como sou de compreendê-la. (Intrinsecamente, meu artigo no Das $\mathrm{Ziel}^{2}$ foi todo na manutenção da ideia do que eu disse anteriormente, mas foi bem difícil de perceber isso uma vez que ele apareceu no local mais inapropriado). De qualquer forma, aprenderei com o que é dito no Der Jude. E assim como minha incapacidade de dizer algo claro sobre o judaísmo neste ponto coincide com o estágio incipiente do jornal, nada nos impede de ter esperanças que possa ainda haver uma coincidência mais favorável nos estágios de nosso desenvolvimento.

É possível que eu possa ir a Heidelberg no final do verão. Ficaria feliz em tentar dinamizar através de uma conversa o que, nesse ponto, eu fui capaz de expressar de maneira tão imperfeita. $\mathrm{E}$, deste ponto de vantagem, pode ser até possível que seja capaz de falar algo sobre o judaísmo. Eu não acredito que meu modo de pensar seja não-judeu desta forma.

Atenciosamente,

Walter Benjamin

1. Scholem esteve com WB de 16 a 18 de Junho

2. "Das Leben der Studenten" 
BENJAMIN, Walter. The correspondence of Walter Benjamin, 1910-1940. Edited and annotated by Gershom Scholem and Theodor W. Adorno; translated by Manfred R. Jacobson and Evelyn M. Jacobson. Frankfurt am Main: Suhrkamp Verlag, 2012. 